\title{
Pengaruh Return on Asset, Free Cash Flow, Debt to Equity Ratio, Pertumbuhan Penjualan Terhadap Kebijakan Dividen Pada Perusahaan Property and Real Estate yang Terdaftar di Bursa Efek Indonesia Periode 2014-2016
}

Hantono $^{1}$

Universitas Prima Indonesia hantono_78@yahoo.com

Andre Hartono 4

Universitas Prima Indonesia andrehtn1106@gmail.com

\author{
Ike Rukmana Sari ${ }^{2}$
}

Universitas Prima Indonesia Universitas Prima Indonesia ikerukmana@yahoo.com felicyalo24@email.com

\author{
Miria Daeli ${ }^{5}$ \\ Universitas Prima Indonesia \\ miriadaeli3@gmail.com
}

\begin{abstract}
Property and real estate companies will make progress for the economy in Indonesia. In this development, investors who invest in this field will have an advantage in dividend distribution in accordance with the shares owned and the increase in stock prices. The purpose of this research is to examine the effect of the return on assets, free cash flow, debt to equity ratio, sales growth to dividen policy on property and real estate companies in Indonesia Stock Exchange in the period 2014-2016. The population in this research are property and real estate companies listed in Indonesia Stock Exchange active from 2014 to 2016 with a sample of 18 companies. Based on analysis, it can be concluded that free cash flow positive and significant effect on dividen policy. Return on assets, debt to equity ratio and sales growth does not effect on dividen policy.
\end{abstract}

Keywords : Return on Assets, Free Cash Flow, Debt to Equity Ratio, Sales Growth , and Dividen Policy.

\section{ABSTRAK}

Perusahaan property and real estate akan memberikan kemajuan bagi perekonomian di Indonesia. Dalam perkembangan tersebut para investor yang berinvestasi dalam bidang ini akan memiliki keuntungan dalam pembagian dividen 
sesuai dengan saham yang dimiliki dan kenaikan harga saham. Penelitian ini bertujuan untuk mengetahui pengaruh return on assets, free cash flow, debt to equity ratio, pertumbuhan penjualan terhadap kebijakan dividen pada perusahaan property and real estate di Bursa Efek Indonesia periode 2014-2016. Populasi dalam penelitian ini adalah perusahaan-perusahaan property and real estate yang tercatat aktif di Bursa Efek Indonesia dari tahun 2014 sampai 2016 dengan sampel 18 perusahaan. Hasil analisis yang telah dilakukan dapat disimpulkan bahwa free cash flow berpengaruh positif dan signifikan terhadap kebijakan dividen. Return on asset, debt to equity ratio dan pertumbuhan penjualan tidak berpengaruh terhadap kebijakan dividen.

Kata kunci : Return on Assets, Free Cash Flow, Debt to Equity Ratio, Pertumbuhan Penjualan , dan Kebijakan Dividen

\section{Pendahuluan}

\subsection{Latar Belakang}

Perusahaan industri property and real estate memiliki dampak yang baik bagi kemajuan perekonomian di Indonesia. Industri property and real estate akan selalu berkembang pesat setiap tahunnya dan mampu menarik minat para investor karena kenaikan harga bangunan dan tanah serta pertumbuhan jumlah penduduk yang terus bertambah setiap tahunnya sehingga memberikan dampak terhadap kebutuhan masyarakat akan tempat yang layak dan nyaman. Seperti dapat dilihat dari semakin banyaknya pembangunan disektor perumahan, apartemen, pusat pembelanjaan dan gedung perkantoran. Dengan terus bertumbuhnya jumlah penduduk, membuat permintaan akan property and real estate cenderung meningkat dan menggundang para investor berinvestasi.

Pertumbuhan ekonomi di Indonesia didukung oleh berbagai sektor yang ada di Indonesia. Masyarakat diharapkan mampu ikut serta dalam menggerakkan perekonomian di Indonesia salah satunya melalui kegiatan pasar modal. Pasar modal menggambarkan keadaan ekonomi suatu negara, dimana semakin maju dan berkembang pasar modal suatu negara, maka semakin maju dan berkembang pula perekonomian suatu negara. Banyak alternatif yang dapat dipilih untuk berinvestasi di pasar modal, salah satunya adalah dengan melakukan pembelian saham-saham. Investasi saham berpotensi memiliki keuntungan dalam dua hal, yaitu pembagian dividen atas laba yang dihasilkan oleh perusahaan sesuai dengan saham yang dimiliki dan kenaikan harga saham (capital gain).

Dividen merupakan pembagian keuntungan yang diberikan perusahaan yang berasal dari keuntungan yang dihasilkan perusahaan. Dividen dibagikan dalam interval waktu yang tetap yaitu setiap setengah tahun atau satu tahun. 
Dividen yang diberikan dapat berupa dividen tunai dan dividen saham. Jika tingkat pengembalian yang diperoleh sesuai dengan yang diharapkan dan resiko investasi yang diproyeksikan bisa diminimalkan maka investor bisa memperoleh dividen yang maksimal. Seorang investor tentunya harus mampu untuk memberikan gambaran tentang bagaimana menempatkan investasinya agar dividen ataupun tingkat pengembalian yang diharapkan bisa maksimal dengan cara mengelola investasinya dengan memperhatikan kondisi pasar modal agar terhindar juga dari resiko investasi yang bisa saja merugikan.

Pembayaran dividen sangat berpengaruh pada laba yang diperoleh perusahaan. Dividen hanya dapat dibayarkan kepada para pemegang saham jika perusahaan memperoleh laba pada tahun yang bersangkutan. Sebingga disimpulkan bahwa profitabilitas mutlak diperlukan untuk perusahaan ketika menerapkan suatu kebijakan pembagian dividen, karena semakin tinggi profitabilitas maka semakin besar jumlah dividen yang dibayarkan.

Free Cash Flow menggambarkan tingkat fleksibilitas keuangan perusahaan. Jika perusahaan memiliki free cash flow maka perusahaan akan membagikannya sebagai dividen. Free Cash Flow merupakan salah satu indikator untuk mengukur kemampuan perusahaan untuk mengembalikan keuntungan bagi para pemegang saham melalui pengurangan hutang, peningkatan dividen atau pembelian saham kembali. Peningkatan dividen merupakan sinyal yang positif tentang pertumbuhan perusahaan di masa yang akan datang, karena meningkatnya dividen diartikan sebagai adanya keuntungan yang akan diperoleh di masa yang akan datang sebagai hasil yang diperoleh dari keputusan investasi yang perusahaan dengan net present value positif. Semakin besar debt to equity ratio ini mencerminkan resiko keuangan perusahaan yang semakin tinggi, karena modal yang dimiliki tidak mampu untuk menutupi utang-utang perusahaan. Peningkatan utang akan memengaruhi besar kecilnya laba bersih yang tersedia bagi para pemegang saham termasuk dividen yang diterima karena kewajiban untuk membayar utang lebih diutamakan daripada pembagian dividen.

Pertumbuhan penjualan juga merupakan bahan pertimbangan para investor dalam menanamkan sahamnya. Jika pertumbuhan penjualan dari tahun ke tahun selalu naik, maka dapat dikatakan perusahaan tersebut mempunyai prospek yang baik di masa yang akan datang. Semakin tinggi tingkat pertumbuhan penjualan, maka semakin tinggi juga tingkat keuntungan yang dihasilkan oleh perusahaan. Dengan meningkatnya keuntungan perusahaan maka pembagian dividen juga akan semakin tinggi. 


\subsection{Tujuan penelitian}

Adapun tujuan dari penelitian ini adalahuntuk menguji dan menganalisi pengaruh Return on Assets secara parsial terhadap Kebijakan Dividen pada Perusahaan Property and Real Estate yang terdaftar di Bursa Efek Indonesia periode 2014-2016, pengaruh Free Cash Flow secara parsial terhadap Kebijakan Dividen pada Perusahaan Property and Real Estate yang terdaftar di Bursa Efek Indonesia periode 2014-2016,

$$
\text { Return On Asset }=\frac{\text { Laba Bersih }}{\text { Total Aset }}
$$

pengaruh Debt to Equity Ratio secara parsial terhadap Kebijakan Dividen pada Perusahaan Property and Real Estate yang terdaftar di Bursa Efek Indonesia periode 2014-2016, pengaruh Pertumbuhan Penjualan secara parsial terhadap Kebijakan Dividen pada Perusahaan Property and Real Estate yang terdaftar di Bursa Efek Indonesia periode 20142016, pengaruh Return on Assets, Free Cash Flow, Debt to Equity Ratio, Pertumbuhan Penjualan secara simultan terhadap Kebijakan Dividen pada Perusahaan Property and Real Estate yang terdaftar di Bursa Efek Indonesia periode 2014-2016.

\section{Kajian Pustaka}

\subsection{Return on Assets}

Harahap (2016:305) bahwa return on assets (ROA) menggambarkan perputaran aktiva diukur dari penjualan. Semakin besar rasio ini maka semakin baik dan hal ini berarti bahwa aktiva dapat lebih cepat berputar dan meraih laba.

Hery (2015:228) menyatakan bahwa hasil pengembalian atas aset (Return on Assets) merupakan rasio yang menunjukkan seberapa besar kontribusi aset dalam menciptakan laba bersih.

Return on Asset dapat disimpulkan sebagai rasio yang digunakan untuk megukur keefetivitsan perusahaan dalam menghasilkan laba dengan menggunakan seluruh aktiva yang dimiliki.

Hery (2015:228), rumus yang dapat digunakan untuk menghitung Return on Assets adalah:

\subsection{Free Cash Flow}

Sartono (2010:101), menyatakan bahwa free cash flow merupakan arus kas yang disediakan untuk dibagikan kepada para pihak investor setelah melakukan investasi pada fixed asset dan working capital yang diperlukan oleh perusahaan untuk dapat mempertahankan kelangsungan usahanya.

Syahyunan (2013:35), free cash flow merupakan arus kas yang disediakan kepada pihak-pihak yang berkepentingan terhadap perusahaan, seperti kreditor dan investor.

Free cash flow dapat disimpulkan sebagai sisa dari perhitungan arus kas yang dihasilkan oleh perusahaan di akhir periode keuangan setelah membayar gaji, biaya produksi, tagihan, cicilan hutang berikut bunganya, pajak, dan juga belanja modal (capital expenditure) untuk 
pengembangan usaha.

Syahyunan (2013:35), rumus yang digunakan untuk mencari free cash flow adalah :

Arus kas bebas $=$ arus kas operasi + arus kas investasi

\subsection{Debt to Equity Ratio}

Harahap (2016:303), debt to equity ratio menggambarkan sampai sejauh mana modal pemilik dapat menutupi utang-utang kepada pihak luar.

Jusuf (2016:56) menyatakan bahwa dengan semakin tinggi debt to equity ratio maka risiko kreditor (termasuk bank) semakin besar karena debt to equity ratio yang tinggi berarti

Kenaikan Penjualan T - Penjualan T-1 Penjualan $=$ Penjualan T-1 semakin rendah tingkat keamanan dana yang ditempatkan oleh kreditor dalam bisnis tersebut.

Hantono (2017 : 12) menyatakan bahwa rasio yang menunjukkan sejauh mana modal sendiri menjamin seluruh utang. Rasio ini juga dapat dibaca sebagai perbandingan antara dana pihak luar dengan dana pemilik perusahaan.

Kesimpulannya menyatakan bahwa perusahaan harus berhati-hati dalam penggunaan hutangnya karena semakin tinggi hutang semakin besar resiko yang mengancam kebangkrutan suatu perusahaan.

Kasmir (2015:158), rumus untuk mencari Debt to Equity Ratio adalah :

Debt to Equity $\quad$ Total Utang (Debt) Ratio $=\quad$ Ekuitas (Equity)

\subsection{Pertumbuhan Penjualan}

Subramanyam \& Wild (2011:172173) menyatakan bahwa pertumbuhan penjualan merupakan akibat dari satu atau beberapa faktor termasuk dalam perubahan harga, perubahan volume, akuisisi/divestasi dan perubahan nilai tukar.

Harahap (2016:310) menggambarkan suatu persentasi dari kenaikan penjualan tahun ini dibanding dengan tahun lalu.

Kesimpulannya menyatakan pertumbuhan penjualan merupakan cerminan keberhasilan investasi pada periode masa lalu dan dapat dijadikan sebagai prediksi pertumbuhan dimasa yang akan datang.

Harahap (2016:309), rumus dalam mencari sales growth yaitu :

\subsection{Kebijakan Dividen}

Harmono (2015:12) menggambarkan suatu persentase laba yang dibayarkan kepada para pemegang saham dalam bentuk dividen tunai, penjagaan stabilitas dividen dari waktu ke waktu, pembagian dividen saham dan pembelian kembali saham.

Sudana (2011:167), menyatakan bahwa kebijakan dividen akan berhubungan dengan penentuan besarnya dividend payout ratio yang merupakan besarnya persentase laba bersih setelah pajak yang dibagikan sebagai dividen kepada pemegang saham. 
Kebijakan dividen dapat disimpulkan sebagai kebijakan yang dapat menentukan seberapa besar atau proporsi laba yang akan dibagikan sebagai dividen.

Sudana (2011: 24), rumus untuk menghitung kebijakan dividen sebagai berikut :

\subsection{Return on Assets Terhadap Kebijakan Dividen}

Rodoni dan Ali (2014:117) menyatakan perusahaan besar yang memiliki tingkat profitabilitas mudah memasuki pasar modal atau memperoleh dana.Halim (2015:23) apabila suatu perusahaan memperoleh profit yang tinggi maka kemungkinan dividen yang dibayarkan juga relatif tinggi.

$\mathrm{H}_{1}$ : Return on Assets memiliki pengaruh pada Kebijakan Dividen

\subsection{Free Cash Flow Terhadap Kebijakan Dividen}

Sartono (2010:293) menyatakan bahwa perusahaan akan menggangap deviden sebagai kas keluar karena besarnya posisi kas dan likuiditas perusahaan secara keseluruhan akan memperbesar kemampuan perusahaan dalam membayarkan dividen.

Hery (2013:32) dalam pembayaran dividen lebih tergantung pada posisi kas karena akan memcerminkan kemampuan perusahaan dalam melakukan pembayaran dividen daripada laba periode berjalan yang dimana akan diperngaruhi oleh praktik akuntansi.

\section{$\mathrm{H}_{2}$ : Free Cash Flow memiliki pengaruh pada Kebijakan Dividen}

\subsection{Debt to Equity Ratio Terhadap Kebijakan Dividen}

Sjahrial (2008:305) menyatakan bahwa jika sebagian besar laba yang digunakan untuk membayar utang

$$
\begin{aligned}
& \text { Dividen Payout } \\
& \text { Ratio }=
\end{aligned}
$$

maka sisanya yang akan digunakan untuk membayar dividen makin kecil.

Riyanto (2009:267) menyatakan bila perusahaan menetapkan bahwa pelunasan utangnya akan diambilkan dari laba ditahan, berarti perusahaan harus menahan sebagian besar dari pendapatannya untuk keperluan tersebut, yang ini berarti bahwa hanya sebagian kecil saja dari pendapatan atau earning yang dapat dibayarkan sebagai deviden. Dengan kata lain perusahaan harus menetapkan dividen payout ratio yang rendah.

$\mathrm{H}_{3}$ : Debt to Equity Ratio memiliki pengaruh pada Kebijakan Dividen

\subsection{Pertumbuhan Penjualan Terhadap Kebijakan Dividen}

Rodoni dan Ali (2014:116) perusahaan-perusahaan yang termasuk dalam kelompok perusahaan yang sedangberkembang akan mampu menghasilkan tingkat pertumbuhan dividen yang lebih tinggi pada tahuntahun berikutnya.

Mulyawan (2015:257) menyatakan bahwa perusahaan akan membayar dividen kepada para pemegang saham 
dengan jumlah yang selalu meningkat dengan pertumbuhan yang stabil.

H4 : Pertumbuhan Penjualan memiliki pengaruh pada Kebijakan Dividen

\subsection{Kerangka Konseptual}

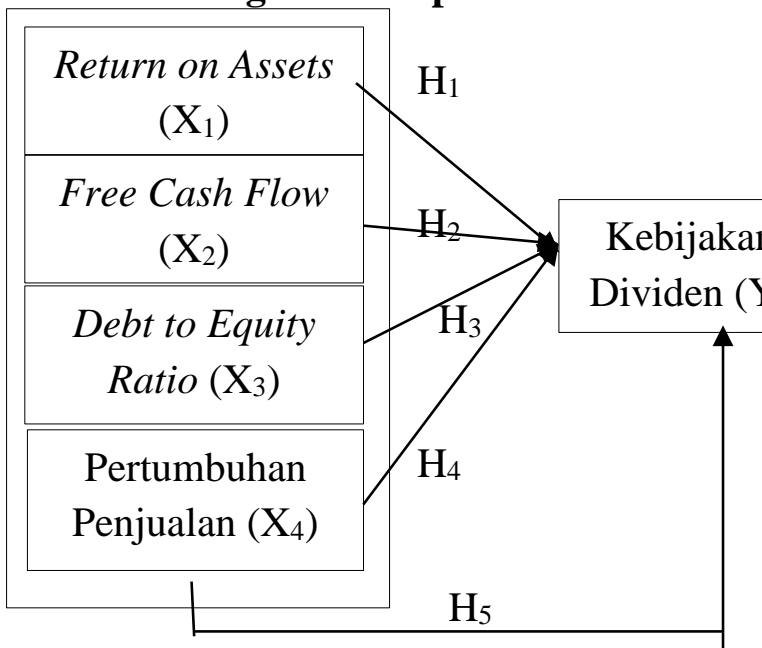

\section{Gambar 1. Rerangka Konseptual}

Berdasarkan kerangka konseptual tersebut, maka dapat disusun hipotesis penelitian sebagai berikut :

$\mathrm{H}_{1,2,3,4}$ : Return on Assets, Free Cash Flow, Debt to Equity Ratio, Pertumbuhan Penjualan berpengaruh secara parsial terhadap Kebijakan Dividen pada Perusahaan Property and Real Estate yang terdaftar di Bursa Efek Indonesia periode 20142016.

$\mathrm{H}_{5}$ : $\quad$ Return on Assets, Free Cash Flow, Debt to Equity Ratio, Pertumbuhan Penjualan berpengaruh secara simultan terhadap Kebijakan Dividen pada Perusahaan Property and Real Estate yang terdaftar di Bursa Efek Indonesia periode 20142016.

\section{Metode Penelitian}

\subsection{Jenis Penelitian}

Jenis Penelitian ini menggunakan pendekatan kuantitatif, bertujuan untuk meneliti populasi atau sampel

entu. Sifat penelitian yaitu pungan sebab akibat yaitu untuk ngetahui pengaruh variabel bebas return on assets, free cash flow, debt to equity ratio, pertumbuhan penjualan dan variabel terikat yaitu kebijakan dividen baik secara parsial maupun simultan. Data yang dipakai adalah yang bersifat sekunder berupa financial report pada perusahaan property and real estate berturut-turut dalam BEI periode 2014-2016.

\subsection{Sampel dan Teknik Pengambilan Sampel}

Populasi penelitian ini adalah perusahaan property and real estate yang terdaftar dalam BEI tahun 20142016 dengan jumlah perusahaan total 49 perusahaan. Teknik pengambilan sampel dengan menggunakan purposive sampling jumlah sampel yang didapatkan yaitu 18 perusahaan dan dikalikan dengan tahun penelitian (3 tahun) maka didapatkan 54 data penelitian. Kriteria untuk pemilihan sampel pemilihan ini adalah :

1. Perusahaan Property and real estate yang listing di Bursa Efek Indonesia periode 2014-2016. 
2. Perusahaan Property and real estate yang membayarkan dividen berturut-turut selama periode 20142016.

3. Perusahaan Property and Real Estate yang mengalami keuntungan selama periode $2014-2016$.

Tabel 1. Kriteria Pengambilan Sampel Penelitian

\begin{tabular}{|c|c|c|}
\hline No & Kriteria & Jlh \\
\hline 1. & $\begin{array}{l}\text { Perusahaan Property } \\
\text { and Real Estate yang } \\
\text { Terdaftar di BEI periode } \\
2014-2016\end{array}$ & 49 \\
\hline 2. & $\begin{array}{l}\text { Perusahaan Property } \\
\text { and Real Estate yang } \\
\text { tidak membayarkan } \\
\text { dividen berturut-turut } \\
\text { selama periode } 2014- \\
2016\end{array}$ & $(8)$ \\
\hline 3. & $\begin{array}{l}\text { Perusahaan Property } \\
\text { and Real Estate yang } \\
\text { mengalami kerugian } \\
\text { selama periode } 2014- \\
2016\end{array}$ & $(23)$ \\
\hline \multicolumn{2}{|c|}{ Jumlah Sampel Perusahaan } & 18 \\
\hline \multicolumn{2}{|c|}{ Total Sampel (18 x 3 tahun) } & 54 \\
\hline
\end{tabular}

\subsection{Metode Analisis}

Metode penelitian yang digunakan adalah analisis kuantitatif, metode dalam penelitian ini adalah model regresi linier berganda melalui aplikasi SPSS.

\section{Hasil dan Pembahasan}

\subsection{Statistik deskriptif}

Hasil dari pengolahan data dapat dilihat dari statistik deskriptif dibawah ini :

Tabel 2 . Statistik Deskriptif

Descriptive Statistics

\begin{tabular}{|l|r|r|r|r|r|}
\hline & N & \multicolumn{1}{|c|}{ Minimum } & \multicolumn{1}{|c|}{ Maximum } & Mean & \multicolumn{1}{c|}{ Std. Deviation } \\
\hline ROA & 54 &, 01 &, 18 &, 0793 &, 03988 \\
FCF & 54 & $-35279191325000,00$ & 1090023211073,00 & $-1043082347049,8150$ & 4823222300618,0 \\
DER & 54 &, 15 & 1,80 &, 8751 &, 40394 \\
PERTUMBUHAN_PENJU & 54 & -37 &, 81 &, 1059 &, 21561 \\
ALAN & 54 &, 04 &, 89 &, 1878 &, 15149 \\
DPR & 54 & & & & \\
Valid N (listwise) & 54 & & & & \\
\hline
\end{tabular}

\subsection{Hasil uji asumsi klasik}

\subsubsection{Uji normalitas}

Uji normalitas bertujuan untuk menguji apakah dalam model regresi,

variabel pengganggu atau residual memiliki distribusi normal. Hasil uji normalitas dapat berupa tabel statistik Kolmogorov Smirnov. Dalam uji ini, pedoman yang digunakan dalam pengambilan keputusan adalah :

1. Jika nilai signifikan lebih besar dari 0,05 maka distribusi normal.

2. Jika nilai signifikan lebih kecil dari 0,05 maka distribusi tidak normal.

Hasil dari pengujian normalitas menggunakan tabel statistik Kolmogorov Smirnov pada penelitian ini adalah sebagai berikut : 
Tabel 3 . Uji Normalitas menggunakan Kolmogorov Smirnov

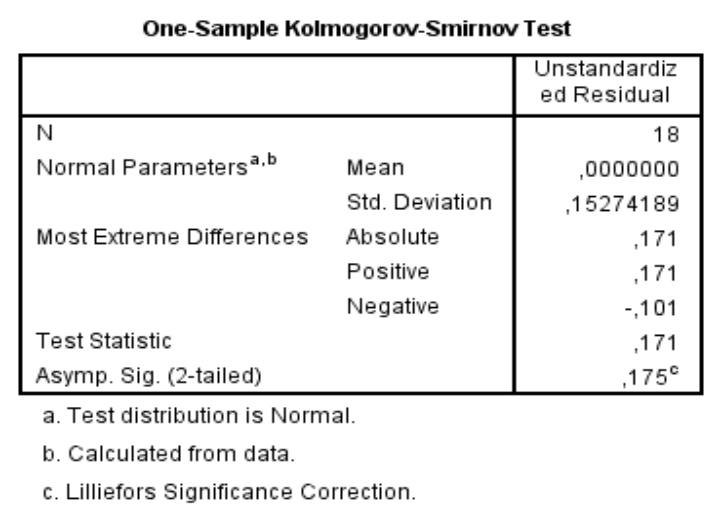

Hasil uji statistik normalitas Kolmogorov Smirnov dalam penelitian ini menunjukkan nilai signifikan 0,175 $>0,05$ dengan demikian dapat diambil kesimpulan bahwa dalam hasil uji statistik normalitas Kolmogorov Smirnov data berdistribusi normal.

\subsubsection{Uji multikolinearitas}

Uji multikolinearitas bertujuan untuk menguji apakah model regresi ditemukan adanya korelasi antar variabel bebas (independen). Model regresi yang baik seharusnya tidak terjadi korelasi antar variabel independen.

Untuk mendeteksi ada atau tidaknya multikolinearitas di dalam model regresi dapat dilihat dari :

1. Nilai tolerance dan lawannya.

2. Variance Inflation Factor (VIF).

Cara pengambilan keputusannya yaitu nilai tolerance $>0,10$ dan nilai variance inflation factor (VIF) $<10$ maka regresi bebas multikolinieritas.

Hasil Pengujian multikolonieritas yang digunakan dalam penelitian ini dapat dilihat pada tabel berikut:

Tabel 4 . Uji Multikolonieritas

\begin{tabular}{|c|c|c|c|}
\hline \multicolumn{4}{|c|}{ Coefficients $^{a}$} \\
\hline \multirow[b]{2}{*}{ Model } & & \multicolumn{2}{|c|}{ Collinearity Statistics } \\
\hline & & Tolerance & VIF \\
\hline 1 & SQRT_ROA & 593 & 1,687 \\
\hline & SQRT_FCF & ,481 & 2,080 \\
\hline & SQRT_DER &, 818 & 1,223 \\
\hline & $\begin{array}{l}\text { SQRT_PERTUMBUHAN_ } \\
\text { PENJUALAN }\end{array}$ &, 634 & 1,577 \\
\hline
\end{tabular}

a. Dependent Variable: SQRT_DPR

Berdasarkan pengujian multikolinearitas pada tabel di atas, model regresi tidak terjadi korelasi antar variabel independen karena nilai tolerance variabel return on assets, free cash flow, debt to equity ratio dan pertumbuhan penjualan berada di atas 0,10 sedangkan nilai VIF variabel return on assets, free cash flow, debt to equity ratio dan pertumbuhan penjualan berada di bawah 10 .

\subsubsection{Uji autokorelasi}

Uji autokorelasi bertujuan untuk menguji apakah dalam model regresi linear ada korelasi antara kesalahan pengguna pada periode $\mathrm{t}-1$ (sebelumnya). Pengujian autokorelasi dengan menggunakan run-test dapat disajikan sebgai berikut : 
Tabel 5. Uji Autokorelasi

\begin{tabular}{|l|r|}
\multicolumn{2}{c}{ Runs Test } \\
\hline \multicolumn{1}{|c|}{} & $\begin{array}{c}\text { Unstandardiz } \\
\text { ed Residual }\end{array}$ \\
\hline Test Value $^{\text {a }}$ &,- 03818 \\
Cases < Test Value & 9 \\
Cases > = Test Value & 9 \\
Total Cases & 18 \\
Number of Runs & 11 \\
Z &, 243 \\
Asymp. Sig. (2-tailed) &, 808 \\
\hline
\end{tabular}

Dari tabel 5 diatas menunjukkan asymp.sig pada output run test sebesar $0,808>0,05$, maka data tidak mengalami autokorelasi.

\section{Uji Heteroskedastisitas}

Uji heteroskedastisitas bertujuan menguji apakah dalam model regresi terjadi ketidaksamaan variance dari residual pengamatan satu ke pengamatan lain. Untuk mengetahui ada tidaknya heteroskedastisitas dapat digunakan uji Park. Uji Park mengemukakan metode bahwa variance $\left(\mathrm{s}^{2}\right)$ merupakan fungsi variabel independen. Pengujian heteroske-dastisitas dapat dilihat pada tabel berikut :

Tabel 6. Uji Heteroskedastisitas dengan Uji Park

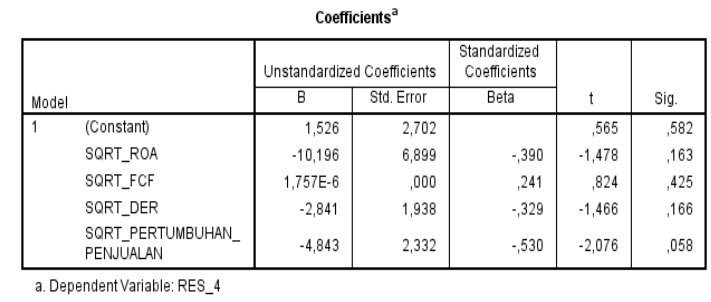

Pengujian pada model regresi di atas tidak menunjukkan gejala pada heteroskedastisitas karena nilai signifikan variabel rasio return on assets, free cash flow, debt to equity ratio dan pertumbuhan penjualan berada di atas 0,05.

\subsection{Hasil analisis data penelitian 4.3.1 Model penelitian}

Pengujian hipotesis penelitian yang digunakan adalah regresi linier berganda. Analisis regresi linier berganda digunakan untuk mencari hubungan atau pengaruh antar variable independen (return on assets, free cash flow, debt to equity ratio dan pertumbuhan penjualan) terhadap variable dependen ( kebijakan dividen).

\section{Tabel 7. Model Penelitian}

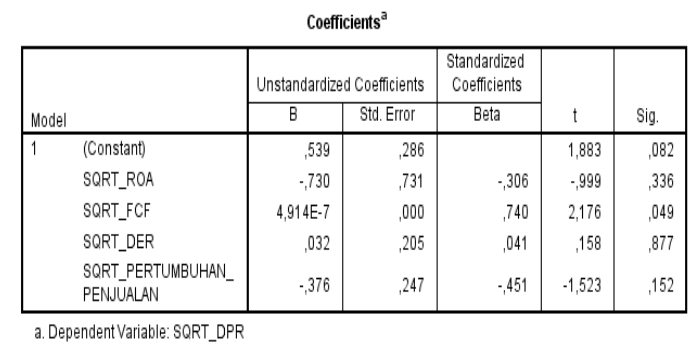

Persamaan regresi linier berganda dalam penelitian ini berdasarkan table 7 tersebut sebagai berikut : SQRT_KEBIJAKAN_DIVIDEN= 0,539 - $0,730 \quad$ SQRT_ROA + 4,914SQRT_FCF $+0,032$ SQRT DER - 0,376 SQRT_ PERTUM BUHAN_PENJUALAN

\subsubsection{Koefisien Determinasi Hipotesis}

Koefisien determinasi ditujukan untuk mengetahui seberapa besar kemampuan model dalam menerangkan variabel terikat. Jika 
koefisien determinasi $\left(\mathrm{R}^{2}\right)$ semakin besar atau mendekati 1, maka dapat dikatakan bahwa kemampuan variabel bebas (X) adalah besar terhadap variabel terikat (Y).

\section{Tabel 8. Koefisien Determinasi Hipotesis}

\begin{tabular}{|c|c|c|c|c|}
\hline \multicolumn{5}{|c|}{ Model Summary ${ }^{b}$} \\
\hline Model & $\mathrm{R}$ & R Square & $\begin{array}{l}\text { Adjusted R } \\
\text { Square }\end{array}$ & $\begin{array}{l}\text { Std. Error of } \\
\text { the Estimate }\end{array}$ \\
\hline 1 & $.527^{\mathrm{a}}$ & 278 &, 055 & 17467 \\
\hline
\end{tabular}

Hasil uji koefisien determinasi diperoleh nilai $\mathrm{R}$ square sebesar 0,278 . Hal ini berarti $27,8 \%$ dari variabel dependen kebijakan dividen dapat dijelaskan oleh variabel independen return on assets, free cash flow, debt to equity ratio dan pertumbuhan penjualan sedangkan sisanya sebesar $72,2 \%(100 \%-27,8 \%)$ dijelaskan oleh variabel-variabel lain di luar dari variabel yang diteliti.

\subsubsection{Pengujian Hipotesis Secara Simultan (Uji F)}

Uji F digunakan untuk menunjukkan apakah semua variabel independen yang dimasukkan dalam model mempunyai pengaruh secara bersamasama terhadap variabel dependen. Untuk menguji hipotesis ini digunakan statistik F sebagai berikut :

1. Jika $F_{\text {hitung }} \leq \mathrm{F}_{\text {tabel }} ;$ maka $\mathrm{H}_{0}$ diterima dan $\mathrm{H}_{\mathrm{a}}$ ditolak, pada $\alpha=$ 0,05 .

2. Jika $\mathrm{F}_{\text {hitung }}>\mathrm{F}_{\text {tabel }}$; maka $\mathrm{H}_{0}$ ditolak dan $\mathrm{H}_{\mathrm{a}}$ diterima, pada $\alpha=0,05$
Pengujian hipotesis penelitian (Uji F) ini adalah :

a. $\mathrm{H}_{0}$ diterima dan $\mathrm{H}_{\mathrm{a}}$ ditolak (Return on Assets, Free Cash Flow, Debt to Equity Ratio, Pertumbuhan Penjualan secara simultan tidak berpengaruh terhadap Kebijakan Dividen pada Perusahaan Property and Real Estate yang terdaftar di Bursa Efek Indonesia periode 2014-2016).

b. $\mathrm{H}_{0}$ ditolak dan $\mathrm{H}_{\mathrm{a}}$ diterima (Return on Assets, Free Cash Flow, Debt to Equity Ratio, Pertumbuhan Penjualan secara simultan berpengaruh terhadap Kebijakan Dividen pada Perusahaan Property and Real Estate yang terdaftar di Bursa Efek Indonesia periode 2014-2016).

\section{Tabel 9. Uji F}

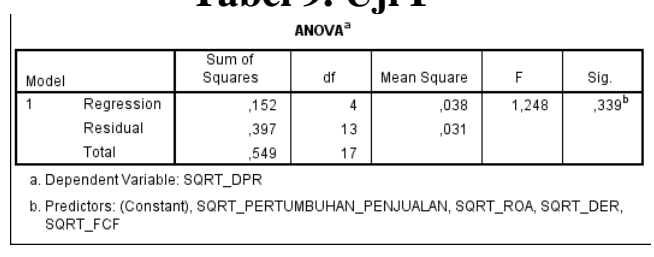

Uji signifikan simultan / bersamasama (uji statistik F) menghasilkan nilai $\mathrm{F}$ hitung sebesar 1,248. Pada derajat bebas $1\left(\mathrm{df}_{1}\right)=\mathrm{k}-1=5-1=4$, dan derajat bebas $2\left(\mathrm{df}_{2}\right)=\mathrm{n}-\mathrm{k}=54-5$ $=49$, nilai $\mathrm{F}_{\text {tabel }}$ pada taraf kepercayaan signifikan 0,05 adalah 2,56. Dengan demikian $\mathrm{F}_{\text {hitung }}=1,248<\mathrm{F}_{\text {tabel }}=2,56$ dengan tingkat signifikan $0,339>$ 0,05 . Maka $\mathrm{H}_{\mathrm{o}}$ diterima artinya secara simultan Return on Assets, Free Cash Flow, Debt to Equity Ratio, Pertumbuhan Penjualan secara simultan tidak berpengaruh terhadap Kebijakan Dividen pada Perusahaan 
Property and Real Estate yang terdaftar di Bursa Efek Indonesia periode 2014-2016.

\subsubsection{Pengujian Hipotesis Secara Parsial (Uji t)}

Uji t digunakan untuk menunjukkan seberapa jauh pengaruh satu variabel independen terhadap variabel dependen. Kriteria pengambilan keputusan mengikuti aturan berikut :

1. Jika - $t_{\text {tabel }} \leq t_{\text {hitung }} \leq t_{\text {tabel }} ;$ maka $\mathrm{H}_{0}$ diterima dan $\mathrm{H}_{\mathrm{a}}$ ditolak, pada $\alpha=$ 0,05 .

2. Jika $t_{\text {hitung }}<-t_{\text {tabel }}$ atau $t_{\text {hitung }}>t_{\text {tabel }}$ ; maka $\mathrm{H}_{0}$ ditolak dan $\mathrm{H}_{\mathrm{a}}$ diterima, pada $\alpha=0,05$

Pengujian hipotesis penelitian (Uji t) ini adalah :

1. $\mathrm{H}_{0}$ diterima dan $\mathrm{H}_{\mathrm{a}}$ ditolak (Return on Assets, Free Cash Flow, Debt to Equity Ratio, Pertumbuhan Penjualan secara parsial tidak berpengaruh terhadap Kebijakan Dividen pada Perusahaan Property and Real Estate yang terdaftar di Bursa Efek Indonesia periode 2014-2016).

2. $\mathrm{H}_{0}$ ditolak dan $\mathrm{H}_{\mathrm{a}}$ diterima (Return on Assets, Free Cash Flow, Debt to Equity Ratio, Pertumbuhan Penjualan secara parsial berpengaruh terhadap Kebijakan Dividen pada Perusahaan Property and Real Estate yang terdaftar di Bursa Efek Indonesia periode 2014-2016).

\section{Tabel 10. Uji t}

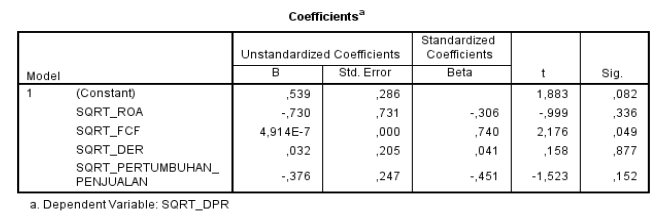

Hasil uji t dapat dijelaskan bahwa return on assets memiliki nilai signifikan sebesar 0,336>0,05 artinya return on assets tidak berpengaruh secara parsial terhadap kebijakan dividen. Free cash flow dengan nilai signifikan sebesar 0,049 $<0,05$ maka free cash flow berpengaruh secara parsial terhadap kebijakan dividen. Debt to equity ratio mempunyai nilai signifikan sebesar 0,877>0,05 maka debt to equity ratio tidak berpengaruh secara parsial terhadap kebijakan dividen. Pertumbuhan Penjualan menghasilkan nilai signifikan sebesar $0,152>0,05$ maka Pertumbuhan Penjualan tidak berpengaruh secara parsial terhadap kebijakan dividen.

\subsection{Pembahasan}

4.4.1 Pengaruh return on assets terhadap kebijakan dividen.

Dari hasil pengujian hipotesis secara statistik diperoleh hasil dengan nilai $-t_{\text {hitung }}>-t_{\text {tabel }}(-0,999>-2,00958)$ dengan nilai signifikansi $0,336>0,05$ yang menunjukkan bahwa return on assets tidak memiliki pengaruh terhadap kebijakan dividen pada perusahaan property and real estate yang terdaftar di Bursa Efek Indonesia periode 2014-2016. Penelitian ini sejalan dengan penelitian sebelumnya yang dilakukan oleh Novita Sari dan Sudjarni (2015) dengan judul 
"Pengaruh Likuiditas, Leverage, Pertumbuhan Penjualan dan Profitabilitas terhadap Kebijakan Dividen Pada Perusahaan Manufaktur di BEI" yang menyatakan bahwa return on assets tidak berpengaruh signifikan terhadap kebijakan dividen.

\subsubsection{Pengaruh free cash Flow terhadap kebijakan dividen.}

Dari hasil pengujian hipotesis secara statistik diperoleh hasil dengan nilai $\mathrm{t}$ hitung $>\mathrm{t}$ tabel $(2,176>$ 2,00958) dengan nilai signifikansi $0,049<0,05$ yang menunjukkan bahwa free cash flow memiliki pengaruh positif signifikan terhadap kebijakan dividen pada perusahaan property and real estate yang terdaftar di Bursa Efek Indonesia periode 20142016. Penelitian ini sejalan dengan penelitian sebelumnya yang dilakukan oleh Natalia dan Santoso (2017) dengan judul " Pengaruh Arus Kas Bebas, Pertumbuhan Perusahaan, Rasio Total Utang dan Modal Sendiri, Rasio Laba Bersih dan Total Aset terhadap Kebijakan Deviden" yang menyatakan arus kas bebas (free cash flow) berpengaruh signifikan terhadap kebijakan dividen.

Penelitian ini tidak sejalan dengan penelitian sebelumnya yang dilakukan Diana dan Hutasoit (2017) dengan judul "Pengaruh Free Cash Flow dan Kepemilikan Institusional terhadap Kebijakan Dividen dengan Profitabilitas sebagai variabel Moderating" yang menyatakan free cash flow tidak berpengaruh signifikan terhadap kebijakan dividen

\subsubsection{Pengaruh debt to equity ratio terhadap kebijakan dividen.}

Dari hasil pengujian hipotesis secara statistik diperoleh hasil dengan nilai $\mathrm{t}$ hitung $<\mathrm{t}$ tabel $(0,158<$ 2,00958) dengan nilai signifikansi $0,877>0,05$ yang menunjukkan bahwa debt to equity ratio tidak memiliki pengaruh terhadap kebijakan dividen pada perusahaan property and real estate yang terdaftar di Bursa Efek Indonesia periode 20142016. Penelitian ini sejalan dengan penelitian sebelumnya yang dilakukan oleh Sunaryo (2014) yang berjudul "Analisis Faktor-faktor yang mempengaruhi Dividen Payout Ratio pada Perusahaan Sektor Industri yang Terdaftar di Bursa Efek Indonesia" yang menyatakan debt to equity ratio tidak berpengaruh terhadap dividen payout ratio.

Penelitian ini tidak sejalan dengan penelitian sebelumnya yang dilakukan oleh Novita Sari dan Sudjarni (2015) dengan judul "Pengaruh Likuiditas, Leverage, Pertumbuhan Penjualan dan Profitabilitas terhadap Kebijakan Dividen Pada Perusahaan Manufaktur di BEI" yang menyatakan bahwa debt to equity ratio berpengaruh negatif dan signifikan terhadap kebijakan dividen.

\subsubsection{Pengaruh pertumbuhan penjualan terhadap kebijakan dividen.}

Menunjukkan hasil pengujian hipotesis secara parsial (Uji-t) dengan data setelah transformasi diperoleh hasil dengan nilai -t hitung 
$>-t$ tabel $(-1,523>-2,00958)$ dengan nilai signifikansi $0,152>0,05$ yang menunjukkan bahwa pertumbuhan penjualan tidak memiliki pengaruh terhadap kebijakan dividen pada perusahaan property and real estate yang terdaftar di Bursa Efek Indonesia periode 2014-2016. Penelitian ini sejalan dengan penelitian sebelumnya yang dilakukan oleh Darmayanti dan Mustanda (2016) yang berjudul "Pengaruh Pertumbuhan Penjualan, Jaminan Aset dan Ukuran Perusahaan terhadap Kebijakan Dividen pada Sektor Industri Barang Konsumsi" yang menyatakan pertumbuhan penjualan tidak berpengaruh terhadap kebijakan dividen.

Penelitian ini tidak sejalan dengan penelitian sebelumnya yang dilakukan oleh Luisiana dan Saputra (2015) yang berjudul "Pengaruh Likuiditas, Profitabilitas dan Pertumbuhan Penjualan terhadap Kebijakan Dividen" yang menyatakan pertumbuhan penjualan berpengaruh positif dan signifikan terhadap kebijakan dividen.

\subsubsection{Pengaruh return on assets, free} cash flow, debt to equity ratio, pertumbuhan penjualan terhadap kebijakan dividen.

Dari hasil penelitian diperoleh demikian $F_{\text {hitung }}<F_{\text {tabel }} 1,248<2,56$ dengan tingkat signifikan $0,339>$ 0,05 . Maka secara simultan return on assets, free cash flow, debt to equity ratio, pertumbuhan penjualan tidak berpengaruh terhadap kebijakan dividen pada perusahaan property and real estate yang terdaftar di Bursa Efek Indonesia periode 2014-2016.

\section{Penutup}

\subsection{Kesimpulan}

Kesimpulan dari hasil penelitian ini adalah:

1. Return on Assets, Free Cash Flow, Debt to Equity Ratio, Pertumbuhan Penjualan secara simultan tidak berpengaru $\mathrm{h}$ terhadap Kebijakan Dividen pada Perusahaan Property and Real Estate yang terdaftar di Bursa Efek Indonesia periode 2014-2016.

2. Return on Assets, Debt to Equity Ratio, Pertumbuhan Penjualan secara parsial tidak berpengaruh terhadap Kebijakan Dividen pada Perusahaan Property and Real Estate yang terdaftar di Bursa Efek Indonesia periode 2014-2016.

3. Free Cash Flow secara parsial berpengaruh positif dan signifikan terhadap Kebijakan Dividen pada Perusahaan Property and Real Estate yang terdaftar di Bursa Efek Indonesia periode 2014-2016.

\subsection{Saran}

Saran dari penelitian ini adalah:

1. Bagi perusahaan property and real estate, agar pihak manajemen mempertim-bangkan return on assets, free cash flow, debt to equity ratio, pertumbuhan penjualan karena variabel ini dapat mempengaruhi kebijakan dividen.

2. Bagi investor, jika ingin berinvestasi pada perusahaan property and real estate yang 
terdaftar di Bursa Efek Indonesia dapat memperhatikan return on assets, free cash flow, debt to equity ratio, pertumbuhan penjualan yang mempengaruhi kebijakan dividen.

3. Bagi peneliti selanjutnya, disarankan untuk menambah variabel lain, seperti Likuiditas dan Ukuran Perusahaan karena hasil koefisien determinasi menunjukkan $72,2 \%$ variabel kebijakan dividen dipengaruhi oleh variabel lain.

\section{DAFTAR RUJUKAN}

Darmayanti, Ni Kadek Desi dan I Ketut Mustanda. Pengaruh Pertumbuhan Penjualan, Jaminan Aset dan Ukuran Perusahaan terhadap Kebijakan Dividen pada Sektor Industri Barang Konsumsi. EJurnal Manajemen Unud. Vol.5, No.8. ISSN : 23028912.

Diana, Nur dan Hasudungan Hutasoit. (2017). Pengaruh Free Cash Flow dan Kepemilikan Institusional terhadap Kebijakan Dividen dengan Profitabilitas sebagai variabel Moderating. Jurnal Akuntansi Manajerial. ISSN (E) : 25026704. Vol.2, No.2.

Halim, Abdul. (2015). Analisis Investasi di Aset Keuangan. Jakarta : Mitra Wacana Media.

Hantono. (2017). Konsep Analisa Laporan Keuangan dengan
Pendekatan Rasio dan SPSS. Yogyakarta : Deepublish

Harahap, Sofyan Safri. (2016). Analisis Kritis atas Laporan Keuangan. Jakarta: PT Raja Grafindo Persada.

Harmono. (2015). Manajemen Keuangan Berbasis Balances Scorecard Pendekatan Teori, Kasus dan Riset Bisnis. Jakarta: Bumi Aksara.

Hery. (2013). Rahasia Pembagian Dividen \& Tata Kelola Perusahaan. Yogyakarta: Gava Media.

Hery. (2015). Analisis Laporan Keuangan Pendekatan Rasio Keuangan. Cetakan Pertama. Yogyakarta : CAPS.

Jusuf. (2016). Analisis Kredit untuk Account Officer. Jakarta: PT. Gramedia Pustaka Utama.

Kartika, Amaliya Viva, dkk. (2015). Pengaruh Return on Assets, Return on Equity dan Assets Grwoth terhadap Dividen Payout Ratio (Studi pada Perusahaan Manufaktur yang Terdaftar di Bursa Efek Indonesia periode 2010-2012). Jurnal Administrasi Bisnis (JAB). Vol 1,No.2.

Kasmir. (2015). Analisis Laporan Keuangan. Cetakan kelima 
Jakarta: Penerbit PT. RajaGrafindo Persada.

Mulyawan, Setia. (2015). Manajemen Keuangan. Bandung: CV. Pustaka Setia.

Natalia, Ethelin dan Hendra F.Santoso (2017). Pengaruh Arus Kas Bebas, Pertumbuhan Perusahaan, Rasio Total Utang dan Modal Sendiri, Rasio Laba Bersih dan Total Aset Terhadap Kebijakan Dividen. Jurnal Akuntansi. Vol.17, No.1.

Novita Sari, Komang Ayu dan Luh Komang Sudjarni (2015). Pengaruh Likuiditas, Leverage, Pertumbuhan Perusahaan dan Profitabilitas Terhadap Kebijakan Dividen pada Perusahaan Manufaktur di BEI. E-Jurnal Manajemen Unud, Vol.4, No.10. ISSN : 2302-8912.

Riyanto, Bambang. (2009). Dasar dasar Pembelanjaan Perusahaan. Cetakan Kedelapan. Yogyakarta : BPFE.

Rodoni, Ahmad, Herni Ali. (2014). Manajemen Keuangan Modern. Jakarta : Mitra Wacana Media.

Sartono, R.Agus. (2014). Manajemen
Keuangan Teori dan Aplikasi. Edisi 4 . Yogyakarta : BPFEYogyakarta.

Sjahrial, Dermawan. (2008). Manajemen Keuangan. Edisi 2. Jakarta: Mitra Wacana Media.

Subramanyam, Wild, dkk. (2011). Analisis Laporan Keuangan. Jakarta: Penerbit Salemba Empat.

Sudana, I Made. (2011). Manajemen Keuangan Perusahaan : Teori \& Praktik. Jakarta : Erlangga

Sunaryo. (2014). Analisis FaktorFaktor yang Mempengaruhi Dividen Payout Ratio pada Perusahaan Sektor Industri yang Terdaftar di Bursa Efek Indonesia. Binus Business Review. Vol.5. No.1.

Syahyunan. 2013. Manajemen Keuangan 1 (Perencanaan, Analisis dan Pengendalian keuangan). Medan: USU Press. 
